\title{
LOOKING AHEAD TO THE END OF TRUSTEESHIP, TRUST TERRITORY OF THE PACIFIC ISLANDS
}

Nearly nine years have passed since the Congress of Micronesia began negotiations with the United States government on the future political status of the Trust Territory of the Pacific Islands after the termination of the present Trusteeship Agreement. In the meantime, the T.T.P.I. has acquired the distinction of being the only one of the 11 post-World War II UN trust territories to remain in that political limbo. Just two years ago the U.S. Administration proposed 1981 as the date at which the present trusteeship status would come to an end, but recent political currents have left Micronesia's political future three years hence more uncertain than ever.

From the very outset of its status negotiations with the U.S., Micronesian representatives have been bargaining for Free Association-a loose relationship with the U.S. in which the latter would assume responsibility for overseeing the islands' foreign affairs and defence, while also providing a stipulated amount of financial assistance each year. ${ }^{1}$ Work on the Compact of Free Association had been progressing slowly but steadily until formal negotiations sputtered to a complete halt in late 1973 after the Seventh Round of the Status Talks. The alleged reason for the breakdown of the talks was a major disagreement between the U.S. and Micronesia over the amount of financial assistance to be offered under Free Association. ${ }^{2}$ It was almost three years before formal negotiations were resumed in May 1976 and a mutually acceptable definition of future U.S. budgetary assistance to Micronesia reached. ${ }^{3}$ Changes were made in the draft compact at the Eighth Round of the Status Talks to give the government of Micronesia wider latitude in foreign affairs and to meet other demands of Micronesian negotiators. Just as momentum seemed to be restored, however, key persons on both negotiating teams were replaced-U.S. Ambassador Franklin Haydn Williams was recalled shortly before the change in administration that came with the election of President Carter, while Senator Lazarus Salii, the Chairman of the Joint Committee on Future Status, was replaced by former Senator Andon Amaraich, 
who was appointed to preside over an entirely new Committee created by the Congress of Micronesia.

But it is neither the turnover on the negotiating team nor the continuing debate over such controversial points as jurisdiction over the 200-mile of $f$-shore economic zone that has presented the greatest obstacle to recent progress in the Status Talks. The political tensions within Micronesia itself have proved the greatest hurdle. The past three years have seen the growth of strong separatist movements in the two administrative districts of Palau and the Marshalls, as well as the complete breakaway of the Northern Marianas from the rest of the Trust Territory. The Northern Marianas, which as early as 1971 had formally made known its desire to secede from the Trust Territory and to seek a closer relationship with the U.S., had its Covenant of Commonwealth approved by the U.S. Congress in March 1976. With a solid $78 \%$ of the Northern Marianas population voting in favour of the Covenant in a special referendum, there was little that even the staunchest advocates of Micronesian unity in Washington could do to oppose the ratification. The following month the Marianas were placed under a separate provisional government, with Erwin D. Canham named as Resident Commissioner. ${ }^{4}$ The Congress of Micronesia (COM), which had strongly opposed the separatist tendencies in the Marianas from the very beginning, finally bowed to the inevitable-while recording its own strong objection to the separation of the Marianas prior to the actual termination of the Trusteeship. 5

Even before the referendum approving the Covenant for the Northern Marianas, there were already loud rumblings in Palau and the Marshalls indiciting: the desire of each of these districts for separate negotiations with the U.S. These rumblings have grown into something of a roar in the past year or two. In March 1974 the Marshall Islands District Legislature adopted a resolution informing the United Nations that it intended to begin its own negotiations with the U.S. 6 At $1 / 1$. time the Marshalls, which was generating a major share of the COM's incorne tux revenues through its U.S.-operated missile base on $\mathrm{K}$ wajalein, were deep in conflict with the Congress over revenue-sharing. Even after the COM passed legislation that turned over to the district legislature half of all locally generated revenue, the separatist movement in the Marshalls continued to grow in strength. The mitial reaction of the U.S. to continuing demands from the Marshalls for separate 
negotiations was to reject them out of hand as incompatible with the unity of the islands that was envisioned in the Trusteeship Agreement. The precedent of the Marianas' breakaway, of course, made this argument less than convincing to Marshallese separatists.

By the summer of 1975 Palau had formally submitted its own request for separate negotiations. Like the Marshalls, Palau quickly formed its own Political Status Commission which it hoped to employ as a negotiating team as soon as the U.S. yielded to its demands for separate talks, and authorized a non-binding referendum in the district to gauge-or perhaps display-the strength of popular separatist desires. The returns of the Palau referendum held in September 1976 showed $88 \%$ in favour of separation, while the vote taken in the Marshalls in July 1977 yielded a $62 \%$ majority for separation. ${ }^{7}$ Despite the very substantial support for separation in Palau and the Marshalls, both districts contain opposition groups that have become ever more vociferous in their stand in favour of Micronesian unity-notably the 'Voice of the Marshalls' group and an anti-separation faction from Pelilieu Island in Palau.

Grow th of separatist tendencies in both districts seems to be solidly rooted in economic considerations. When the U.S. military first publicly presented its future land requirements in Micronesia during the Fifth Round of the Status Talks in July 1972, it specified Palau, the Marshalls and the Northern Marianas as those districts where it wished to acquire or retain the use of existing land and harbour rights. ${ }^{8}$ Along with the military's request, of course, went the unspoken guarantee that the U.S. government would pay well for lease rights to those military retention areas. When the potential tax revenue from the American military or civilian population that would staff those bases was counted in, the U.S. defence requests appeared to be an economic bonanza. For Palau, however, there was an even greater economic boon in the offing. In 1975 Palauan officials were approached by Japanese business interests-chiefly the Nissho-Iwai Corporation and the Industrial Bank of Japan-with a proposal to build a one-half billion dollar supertanker port and oil storage facility on Palau. ${ }^{9}$ The proposed complex would call for utilization of large tracts of land on Babeldaop, the largest island in Palau, and would employ 12,000 persons when in full operation-nearly the equivalent of the district's present population. The proposed superport has in the last two years become a controversial issue in its own right. The leadership of Palau, which has come out 
almost unanimously in support of political autonomy separate from the rest of Micronesia appears to be divided over the superport; several of the traditional leaders are opposed to the plan because of what they regard as its harmful environmental and social impact on the island group. At present the issue is still being debated, while the Nissho-Iwai Corporation completes the environmental impact study that it has undertaken at the request of the Trust Territory Administration.

The separatist desires of Palau and the Marshalls, which at first were largely ignored by the U.S. while the overtures of these districts for separate status negotiations were repeatedly spurned, have of late become too loudly and insistently voiced to be disregarded any longer. Although the U.S. has continually reiterated in official statements its wish to see the remaining districts of the Trust Territory retain some form of political unity at the termination of the Trusteeship, it has lately softened its once strong stance against separate negotiations of any sort. Shortly after his appointment in 1977, the U.S. Representative to the U.S.Micronesian Status Talks, Ambassador Peter Rosenblatt, announced that teams from Palau and the Marshalls would be admitted to future status negotiations. 10 The Congress of Micronesia and its Commission on Future Political Status and Transition would continue to represent only the four central districts of Yap, Truk, Ponape and Kosrae. ${ }^{11}$ Informal talks, under this arrangement, resumed in Molokai in October 1977, although no substantive agreement was reached on any of the key issues. With the presence of three district negotiating teams from Micronesia-all currently attempting to work out some form of Free Association with the U.S.---the talks have necessarily become two-tiered. The U.S. has officially stated its willingness to negotiate a single basic document defining its future political relationship with the six districts and proposes to use the still unfinished draft Compact of Free Association as the working basis for this relationship. To accommodate the desire of the Palau and Marshalls delegation for greater autonomy, however, certain portions of the document would cover those unique aspects of the relationship applicable to each of the three negotiating parties. The new structure for the Status Talks leaves the door open for any other district to begin to negotiate with the U.S. on a bilateral basis, providing that it continues to participate in the multi-lateral negotiations along with the rest of Micronesid. Through the compromise structure that has been recently adopted for talks, the 
U.S. clearly hopes to encourage the districts to establish a common political entity of some sort-however tenuous-while seeking to honour the cries of the two separatist districts for a greater measure of political autonomy.

A lingering question of substantial importance to the success of the Status Talks, now that they have been resumed, is what is to be done with the Micronesian Constitution. In the summer of 1975 representatives from all the districts, including the Marianas, met for three months to assmeble what was designated 'The Constitution for the Federated States of Micronesia'. The Constitution as drafted provides for a parliamentarian central government with limited powers over the districts or 'states'. Inasmuch as the constitution is to be the 'supreme law of the Federated States of Micronesia', ${ }^{12}$ any agreements between Micronesia and other nations-notably the U.S. - would be bound to conform to it. Seemingly shelved during the height of the separatist crisis, the issue of the Constitution has again emerged as a critical one. The Constitution is to be presented to all the districts in a referendum scheduled for 12 July 1978, and if ratified by them it will take effect within a year.

Ambassador Rosenblatt, like his predecessor F. Haydn Williams, holds that the draft Constitution is 'almost at complete variance' with the Free Association that has been the subject of negotiations for several years past, since the Constitution would accord sovereignty to the Micronesian government. ${ }^{13}$ U.S. negotiators maintain that according to the terms of Free Association, sovereignty would reside in the U.S. government. On several occasions recently the U.S. has insisted that supremacy be given to the Compact of Free Association in areas where its provisions might conflict with the Constitution. ${ }^{14}$ The Congress of Micronesia is reluctant to go as far as the U.S. would like in this matter, but it has amended the mandate given to its own Commission on Future Political Status and Transition to allow it to negotiate without feeling constrained by the provisions of the draft Constitution. ${ }^{15}$ Status Talks can now proceed freely for a time without any reference to the Constitution, but eventually the question as to which document shall have precedence over the other must be raised again-and answered.

As attempts to work out a clear foumula for the future political status of the T.T.P.I. continue, efforts are being made to provide a solid economic base for a 
future government. For an island territory that exports a mere $\$ 6$ million in copra and fish while importing $\$ 38$ million worth of foreign goods, this is no small order. $^{16}$ For years the Trust Territory government has been the preponderant factor in the Micronesian economy, employing about as many persons as does the entire private sector. Yearly T.T. budget increases, combined more recently with funds from ever proliferating U.S. federal programmes, appear to have retarded rather than stimulated genuine economic productivity.

Faced with this unpromising situation and a 1981 termination date for the Trusteeship, the Congress of Micronesia contracted in 1976 with the United Nations Development Programme to prepare a five-year economic plan for Micronesia that would help to make the new government of Micronesia self-supporting. A group of International experts who were brought to the Trust Territory to work on the study produced an Indicative Development Plan (IDP) that, with minor changes, was approved by COM and submitted to the districts for adaptation and implementation on the local level. The two basic objectives of the IDP, as stated in the Introduction to the Plan, are:

to correct the present imbalances in the economy ... [ requiring ] a reallocation of resources away from unproductive government expenditures and toward the productive sectors: ... . and to stimulate more production and raise per capita income levels ... [with] high priority on the development of Micronesia's marine and agricultural resources.

Some of the major recommendations made in the IDP have already been at least partially implemented. Recent legislation by the COM has increased the income tax rate and given Micronesia a simple but graduated tax scale. Certain government departments, particularly the Department of Health Services, have increased their fees beyond the former nominal charges in an effort to recoup a greater percentage of their costs. A serious effort to lower the cost of government, however, will require a reduction in the number of Micronesians and expatriates on the government payroll-possibly combined with a lowering of the inflated salaries-inflated in terms of what Micronesia can afford-that are now being paid. The threat of civil suits by public school teachers in three districts when a mandatory 'furlough without pay' was announced may have discouraged further attempts to cut back pay levels or to make slashes in the government work lorce. So far there have been no serious attempts to restrict importation of goods that might be produced locally, nor has there been a noticeable increase in 
agricultural and marine productivity. At this time it appears that legislators and administrators are still undecided on whether to put into effect the unpopular austerity measures that are required to fully implement the IDP and bring Micronesia closer to full self-support, or to walk the easier path of growing reliance on U.S. financia! aid.

Much of Micronesia's hope for future economic prosperity has been pinned on the outcome of the series of Law of the Sea conferences sponsored by the UN, at which representatives from all corners of the globe have been trying to draw up an international treaty to govern the distribution and use of ocean resources. If, as is expected, the international law should eventually establish a 12-mile territorial limit in offshore waters and 188-mile exclusive economic resource zone, land-poor Micronesia would become ocean-rich. All fishing rights (except for certain migrating species) as well as undersea mineral rights over an expanse of waters amounting to nearly two million square miles would belong to Micronesia. The potential wealth from such a vast resource would, many Micronesian leaders anticipate, enable its new government to become entirely self-supporting. Understandably, Micronesian interest in the progress of the Conference has been keen.

In August 1972 the COM created its own Joint Committee on the Law of the Sea, which almost immediately began meetings with the U.S. delegation to the Conference in the hope of having the Micronesian position promoted at forthcoming international meetings. ${ }^{18}$ As the marked difference between the U.S. and Micronesian positions became clear, Micronesian legislators petitioned the U.S. for separate representation at future sessions of the Conference. After refusing this request on at least two separate occasions, the U.S. finally reluctantly agreed to allow the Joint Committee to represent the Micronesian position at the 1974 meeting in Caracas, Venezuela. Thereafter a Micronesian delegation has attended the Conference in a non-voting observer status. In October 1977 legislation passed by the COM was signed into law by the High Commissioner establishing a 200-mile fisheries zone around the islands of Micronesia and authorizing the newly created Micronesian Maritime Authority to regulate this zone. ${ }^{19}$ This law represents the first attempt by the COM to legislate Micronesian control of its offshore waters according to the 200-mile zone concept that has gained wide acceptance at the Law of the Sea Conference. 
The issue is by no means settled, however, An earlier version of this recent legislation was vetoed by the High Comınissioner, in part because it provided for direct negotiations between Micronesia and foreign governments over the concession of fishing and mineral rights. The question of whether Micronesia shall be granted full jurisdiction over the 200-mile economic zone under Free Association is still under dispute at the Status Talks, with the U.S. maintaining that Micronesian control could conflict with U.S. responsibilities under the foreign affairs and defence clauses of the Compact. Implicit in this controversy, of course, is the broader issue of the measure of sovereignty that the Micronesian government-or governments-can expect to exercise at the end of the Trusteeship. After nine years of negotiations, this question is far from being answered. 


\section{FOOTNOTES}

1. A draft of the uncompleted Compact of Free Association was published at the conclusion of the Fifth Round of the Status Talks in August 1972; Joint Committee on Future Status, Draft Compact of Free Association ... Presented to the Congress of Micronesia, Saipan, Aug. 1972.

2. For a summary of the results of the first seven rounds of Status Talks, see Donald McHenry, Micronesia: Trust Betrayed (New York 1975), 87-128, 2404.

3. The level of U.S. support agreed upon under Free Association was an annual allotment of $\$ 57$ million for the first five years, $\$ 52$ million for the second five years, and $\$ 47$ million for the third five.

4. On 11 Jan. 1978 the first elected Governor of the Marianas, Carlos Camacho, assumed office, replacing Canham as the Chief Executive in the New Commonwealth.

5. McHenry, op. cit., 133.

6. McHenry, op. cit., 134.

7. Pacific Daily News, 28 Sept. 1976; 31 Aug. 1977.

8. Joint Committee on Future Status, Draft Compact of Free Association, Annex B.

9. Japan's strict environmental laws rule out the possibility of building the port on its own soil, and according to a preliminary study authored by Robert Panero, Palau was identified as the most feasible site for what came to be known as 'Port Pacific'.

10. Pacific Daily News, 18 Sept. 1977.

11. Kosrae, formerly a part of Ponape, was constituted a separate District on 1 Jan. 1977, thus replacing the Northern Marianas as the sixth star on the Micronesian flag.

12. 'Constitution of the Federated States of Micronesia', Art. II, Section 1.

13. Micronesian Independent, VIII, 7, 23 Dec. 1977, 2.

14. Samuel McPhetres, 'Towards 1981-Micronesian Political Development in 1976', South Pacific Bulletin, XXVI, 4 (1976), 23-5.

15. Public Law No. 7-63, Laws and Resolutions of the Congress of Micronesia, Seventh Congress, First Special Session: August 15-29th, 1977 (Saipan 1977), 39-43. 
16. U.S. Department of State, Trust Territory 1976: 29th Annual Report to the UN (Washington 1976), 204.

17. Congress of Micronesia, Five Year Indicative Development Plan (1976-1981), Saipan, July 1976, 2.

18. Public Law No. 4C-92, Laws and Resolutions of the Congress of Micronesia, Fourth Congress, Second Special Session: August 14-September 2, 1972 (Saipan 1977), 16-8.

19. Public Law No. 7-71, Laws and Resolutions of COM, Seventh Congress, First Special Session, 65-90. 